\title{
Modele narracji o sprawiedliwości systemu wynagradzania
}

\author{
Jacek Wasilewski \\ Katedra Antropologii Mediów, Wydział Dziennikarstwa, Informacji i Bibliologii, \\ Uniwersytet Warszawski
}

Tomasz Rostkowski

Instytut Kapitału Ludzkiego, Kolegium Nauk o Przedsiębiorstwie, Szkoła Główna Handlowa w Warszawie

\begin{abstract}
W artykule autorzy przedstawiają propozycję modelu narracyjnego dotyczącego systemów wynagradzania oraz kryteriów sprawiedliwości związanych z narracjami preferencji. $\mathrm{Na}$ początku omawiają ogólne rozwiązania systemowe w zakresie wynagrodzeń. Następnie łączą rodzaje sprawiedliwości (dystrybutywną, proceduralną, interpersonalną i informacyjną) z klasycznymi teoriami komunikacji, w których wynagrodzenie zostało potraktowane jako komunikat. W artykule przedstawiono propozycję modelu, w którym poszczególnym narracjom zostały przyporządkowane etykiety greckich bogów. Dzięki temu zabiegowi możliwe będzie sformułowanie hipotez badawczych wyjaśniających różnice $\mathrm{w}$ istniejących i preferowanych kryteriach sprawiedliwości dotyczących wynagradzania. Artykuł zawiera propozycję praktycznego wykorzystania modelu w komunikowaniu zasad sprawiedliwości dla różnych organizacji i grup zatrudnionych.
\end{abstract}

Słowa kluczowe: sprawiedliwe wynagradzanie, narracja, system wynagradzania

\section{Wprowadzenie}

Badanie opinii pracowników w Polsce, przeprowadzone w 2017 r. ${ }^{1}$, prezentuje zróżnicowane opinie dotyczące poczucia sprawiedliwości wynagrodzeń. Różne

1 Badanie zostało przeprowadzone w listopadzie 2017 r. na reprezentatywnej próbie pracujących Polaków $(N=1067)$ techniką telefoniczną CATI (Computer Assisted Telephone Interviewing). Stanowi część projektu badawczego nr 2016/21/B/HS4/02992 pt. Sprawiedliwość wynagradzania, finansowanego ze środków Narodowego Centrum Nauki. 
interpretacje sprawiedliwości mogą być spowodowane zarówno odmienną konceptualizacją pracy, jak i różnorodnymi wartościami, którymi kierują się respondenci w życiu społecznym. Artykuł stanowi próbę powiązania sposobów myślenia o systemach wynagradzania i preferencji sprawiedliwych rozwiązań z narracjami, w których te sposoby myślenia są zakorzenione. Wymaga to przedstawienia systemu wynagradzania z wykorzystaniem teorii komunikacji, w którym to systemie zasady przyznawania wynagrodzenia pełnią funkcję komunikatu.

Celem artykułu jest zaproponowanie modelowych ujęć narracji o sprawiedliwym wynagrodzeniu i wynikających z nich kryteriów ustalania należnych wynagrodzeń. Przedstawiono zatem koncept do dalszych badań, w których będzie możliwe postawienie konkretnych hipotez dotyczących zarówno istniejących obecnie systemów wynagradzania, potrzeb pracowników, jak i (a może przede wszystkim) wzajemnego dopasowania percepcji pracowników i najwyższego kierownictwa organizacji.

\section{Systemy wynagradzania a poczucie sprawiedliwości}

Opracowanie modeli narracyjnych wyjaśniających zróżnicowanie poczucia sprawiedliwości wymaga krótkiego przedstawienia podstawowych informacji na temat systemów wynagradzania oraz związanego z nimi poczucia sprawiedliwości i budujących je kryteriów.

Organizacje, zarówno komercyjne (przedsiębiorstwa) jak i niekomercyjne (administracja publiczna, organizacje pozarządowe), istnieją dla realizacji celów, które zostały przed nimi postawione. Te postawione cele mają realizować i wzmacniać cele nadrzędne, które często nie są uświadomione przez pracowników, ale stanowią ostateczne wyjaśnienie powodów istnienia organizacji. Tego rodzaju informacje powinny się znaleźć w strategii organizacji, jej misji, wizji, wartościach i celach, zasadach podziału wypracowanych zasobów. Aby cele mogły być zrealizowane, organizacje budują strategie funkcjonalne w obszarze zarządzania kapitałem ludzkim (ZKL), które coraz częściej są postrzegane nie tyle jako wynikające ze strategii ogólnej organizacji, ile jako pozostające z nią w relacji interaktywnej (Pocztowski, 2006). Systemy zarządzania kapitałem ludzkim obejmują konkretne, połączone ze sobą metody, a sposoby ich wykorzystania mają być spójnym sposobem na realizację celów. Jednym z kluczowych podsystemów ZKL jest podsystem wynagradzania, na który składają się różne elementy. Upraszczając, można powiedzieć, że na podsystem wynagradzania składają się (Borkowska, 2006):

- $\quad$ wynagrodzenia stałe (płace stałe obejmujące zarówno płace zasadnicze, jak $\mathrm{i}$ inne stale wypłacane dodatki), 
- $\quad$ wynagrodzenia zmienne - bodźce krótkoterminowe (jak premie, nagrody) oraz bodźce długoterminowe (np. opcje na akcje),

- świadczenia dodatkowe (np. samochody służbowe, korzyści rekreacyjne i kulturalne czy zdrowotne, dodatkowe wyposażenie stanowiska pracy).

Już to uproszczone zestawienie wskazuje na ogromny zestaw możliwości w budowaniu rozwiązań systemowych w obszarze wynagradzania. Nie mniej złożone są uwarunkowania organizacji, wielorakość ich celów i zakres uświadomionych i nieuświadomionych wartości, którym służą. W końcu kapitał ludzki to skrajnie zróżnicowany czynnik produkcji; każdy pracownik czy kandydat do pracy to indywiduum, które ma nie tylko takie wymierne cechy, jak poziom wykształcenia czy doświadczenia, lecz także cechy, które - odpowiednio ukształtowane i wykorzystane - mogą być największą wartością dla organizacji, tj. stanowić nie tyle „wykonanie pracy, do której wykonania pracownik został zatrudniony”, ile (a może przede wszystkim) potencjał innowacyjności czy kreatywności. Uwarunkowania te nie są, oczywiście, kompletne (pominięto m.in. tak fundamentalne uwarunkowania, jak: sytuacja na rynku dóbr i usług, sytuacja na rynku pracy, uwarunkowania prawne prowadzenia działalności i zatrudnienia, uwarunkowania kulturowe czy moda). Biorąc pod uwagę te uwarunkowania, można stwierdzić, że nie jest możliwe stworzenie jednolitego wzoru idealnego systemu wynagradzania. Konieczna jest budowa zróżnicowanego zestawu rozwiązań modelowych, które mogą wynikać z odmienności rozumienia podstaw czy źródeł sprawiedliwości. Na celowość takiego działania wskazuje jedna z fundamentalnych teorii w zakresie motywowania - teoria sprawiedliwości J.S. Adamsa (1976). Zakładane działania motywacyjne nie będą skuteczne, jeśli potrzeba sprawiedliwości pracowników nie będzie zaspokojona.

W dzisiejszym świecie pracownicy i pracodawcy mają wiele swobody działania. Dzięki temu różne „odmiany” sprawiedliwości wyznawane przez pracodawców mogą „spotykać” na rynku odpowiadające sobie „odmiany” sprawiedliwości pożądane przez pracowników. Mamy do czynienia z potrzebą wzajemnego dostosowania się, czego skrajnym przejawem są sytuacje, w których pracodawcy zwalniają pracowników, ale także pracownicy zmieniają przełożonych, odnajdując innych, bardziej im odpowiadających (Borkowska, 2006).

Z tych uwarunkowań wynikają podstawowe trendy praktyki systemów wynagradzania. Po pierwsze, rosnące znaczenie kapitału ludzkiego wymusza podmiotowe, zindywidualizowane podejście do pracowników i rosnący szacunek do ich potrzeb, co skutkuje stałą aktualizacją systemów wynagradzania. Elastyczność tych zmian dotyczy elementów zarówno ilościowych (zmiana kwot wydatków na wynagrodzenia), jak i jakościowych (zmiana sposobu alokacji środków w odpowiedzi na zmiany potrzeb organizacji i pracowników). Organizacje mogą wprowadzać zmiany ex post, co oznacza, że są one reaktywne, a zatem spóźnione już w chwili 
realizacji (Juchnowicz, 2016). Po drugie, indywidualizacja podejścia sprawia, że inaczej postrzega się problem wynagrodzenia. Jednakże zazwyczaj pracownik nie ma możliwości wyboru poszczególnych elementów systemów wynagradzania oferowanych przez różne organizacje, ale decyduje się na pewien pakiet rozwiązań, który ma swoje ograniczenia. Uwarunkowania kulturowe odpowiednie dla jednego pracownika, nie muszą być w ten sam pozytywny sposób oceniane przez innego, ale wyższe wynagrodzenia będą niemal na pewno pozytywnie oceniane przez wszystkich obecnych i potencjalnych pracowników. Miejsce wynagrodzeń w kompleksowej ocenie propozycji pracodawcy dobrze oddaje koncepcja Total Rewards Strategy, która, wychodząc od uwarunkowań ekonomicznych, rynku pracy, norm kulturowych i regulacji pracy poprzez uwzględnienie strategii biznesu i kultury organizacji, dochodzi do strategii ZKL i wynikającej z niej „łącznej korzyści z pracy", która może obejmować: wynagrodzenia, świadczenia dodatkowe, równowagę zadań prywatnych i zawodowych, uznanie i zarządzanie efektywnością (Sedlak, 2013). Po trzecie, zmienia się postrzeganie ludzi, które można prześledzić nawet na podstawie zmiany określeń pracowników jako czynnika ekonomicznego: od „siły roboczej” do obecnego „kapitału ludzkiego”. Ta zmiana również znalazła odzwierciedlenie w celach budowy systemu wynagradzania. Tradycyjnymi celami systemu były: przyciągnięcie nowych wartościowych kandydatów, utrzymanie w organizacji wartościowych pracowników i motywowanie wartościowych pracowników do realizacji zadań. Oprócz nich obecnie dodaje się jeszcze pozyskanie zaangażowania pracowników, które - według koncepcji zarządzania przez zaangażowanie - służy kreowaniu wartości dla interesariuszy. Koncepcja ta nie tyle "gwarantuje” uzyskanie zaangażowania pracowników, ile „stwarza warunki” do uruchomienia wszystkich, a zatem także nieuświadomionych, możliwości, do wyzwolenia "drzemiących" pokładów energii i kreatywności, aby skuteczniej realizować cele organizacji i niwelować kontrproduktywność (Juchnowicz, 2010).

Warunkami koniecznymi skuteczności działania systemów wynagradzania jest nie tylko ich prawidłowa konstrukcja, odpowiadająca wymaganiom ekonomicznym, lecz także dostosowanie do potrzeb pracowników i prawidłowa komunikacja, która może wpływać na uznanie przez pracowników danych rozwiązań za sprawiedliwe.

Ocena tego, czy coś jest sprawiedliwe, wyraża odczucie, które mamy w stosunku do jakiejś sytuacji związanej z poczuciem odpowiedniego traktowania i wzajemności. Aspekty w literaturze akademickiej dotyczące tego zagadnienia można podzielić na (Deutsch, 2000):

- sprawiedliwość rozdzielczą, obejmującą kryteria, dzięki którym czujemy, że otrzymujemy uczciwy wynik (jakie zasady w danej sprawie uznaje się za sprawiedliwe); w tym obszarze znajdują się takie zasady, jak zasada słuszności i zasług, zasada równości, zasada potrzeb; 
- sprawiedliwość proceduralną, obejmującą sprawiedliwe traktowanie podczas podejmowania i wdrażania decyzji określających wynik (czy wynik jest uzyskany według zasad);

- sprawiedliwość naprawczą i retrybucyjną, odnoszącą się do reakcji na pogwałcenie norm;

- zakres sprawiedliwości, obejmujący zasady dotyczące możliwości uprawnienia do sprawiedliwego traktowania w danej społeczności moralnej;

- poczucie sprawiedliwości, obejmujące czynniki determinujące odczuwanie sprawiedliwości (od nich zależy to, co ostatecznie uważamy za sprawiedliwe).

Poczucie sprawiedliwości można odnieść do trójkąta satysfakcji, w której nasza satysfakcja ze sprawiedliwego przydziału wynagrodzenia dotyczy zarówno jego wysokości (satysfakcja z rezultatu), jak i procesu jego przyznawania (satysfakcja proceduralna) i atmosfery, w jakiej relacja między pracą a wynagrodzeniem się odbywa (satysfakcja emocjonalna) (Moore, 2014). W odniesieniu do tej koncepcji satysfakcji powstawał podział na rozmaite wymiary sprawiedliwości. J.A. Colquitt i J.C. Shaw (2005) wyróżniają cztery wymiary:

1) dystrybucji (dotyczy proporcji między wkładem pracy pracownika a jego wypłatą),

2) procesu (dotyczy postrzegania procesu podziału wynagrodzeń) (zob. Leventhal, 1980),

3) interakcji (dotyczy podmiotowego traktowania pracowników) (zob. Bies, Moag, 1986),

4) interpersonalny (dotyczy relacji między konkretnymi osobami).

Z punktu widzenia nauk o komunikacji jest to próba uwzględnienia zarówno systemu, jak i sposobu i sytuacji jego komunikowania. Przechodząc na pole teorii komunikacji, łatwo można wpisać te czynniki w ogólne modele komunikowania, np. model D.K. Berlo, w którym odbiór komunikatu zależy zarówno od konkretnych cech nadawcy i odbiorcy funkcjonujących w pewnej strukturze społecznej i praktyce kulturowej, jak i od sposobu komunikowania (tabela 1) (Berlo, 1960).

Tabela 1. Model komunikacyjny D.K. Berlo

\begin{tabular}{|l|l|l|l|l|}
\hline Lp. & \multicolumn{1}{|c|}{ Komunikator } & \multicolumn{1}{c|}{ Przekaz } & \multicolumn{1}{c|}{ Kanał } & \multicolumn{1}{c|}{ Adresat } \\
\hline 1 & Kompetencja komunikacyjna & składowe & wzrok & kompetencja komunikacyjna \\
\hline 2 & Postawy & struktura & słuch & postawy \\
\hline 3 & Wiedza & zawartość & dotyk & wiedza \\
\hline 4 & System społeczny & obróbka & węch & system społeczny \\
\hline 5 & Środowisko kulturowe & kod & smak & środowisko kulturowe \\
\hline
\end{tabular}

Źródło: Berlo (1960). 
Jeśli przyjmiemy, że otrzymywane wynagrodzenie jako wymiana pracy za płacę ma wymiar komunikacyjny, to jak każda interakcja, tak i ta wymiana jest „zanurzona” w dyskursie niosącym pewne idee sprawiedliwości. Nadawca określa, co jest brane pod uwagę przy wyznaczaniu wyniku, który zostanie ujęty w procedury. Następnie komunikuje zarówno te procedury (sprawiedliwość proceduralna), jak i poziom uzasadnień ich egzekucji (komunikowanie konkretnego rezultatu sprawiedliwość informacyjna), a także tworzy poprzez techniki retoryczne relacje z odbiorcą, np. dystansując się od negatywnych efektów swoich akcji, redukując poczucie złości u odbiorcy. Odbiorca interpretuje wynik - wysokość wynagrodzenia (sprawiedliwość dystrybutywna) - i ocenia go (dekodowanie przekazu), co przyczynia się do powstania określonej jego postawy i reakcji związanej z poczuciem sprawiedliwości wyniku.

Czynniki dotyczące poczucia sprawiedliwości mogłyby zostać następująco wpisane w ten schemat - tabela 2.

Tabela 2. Model komunikacyjny D.K. Berlo a czynniki wpływające na poczucie sprawiedliwości

\begin{tabular}{|c|c|c|}
\hline Komunikator & Przekaz & Adresat \\
\hline $\begin{array}{l}\text { - Konfiguracja kryteriów } \\
\text { definiujących rezultat } \\
\text { (wzorzec sprawiedliwości } \\
\text { dystrybutywnej) } \\
\text { - Koncepcje sprawiedliwości } \\
\text { - Relacje z odbiorcą } \\
\text { - Kulturowa praktyka i jej } \\
\text { procedury }\end{array}$ & $\begin{array}{l}\text { Komunikat i czynniki } \\
\text { komunikowania wpływające } \\
\text { na poczucie sprawiedliwości: } \\
\text { - postrzeganie procedur jako } \\
\text { jasnych i obiektywnych } \\
\text { (sprawiedliwość } \\
\text { proceduralna) } \\
\text { - poziom informacji } \\
\text { wyjaśniającej wynik } \\
\text { (sprawiedliwość } \\
\text { informacyjna) } \\
\text { kontekst zachowania } \\
\text { nadawcy (sprawiedliwość } \\
\text { interpersonalna) }\end{array}$ & $\begin{array}{l}\text { Ocena wyniku (poczucie } \\
\text { sprawiedliwości): } \\
\text { - możliwość odniesienia do } \\
\text { reguł ogólnych } \\
\text { - } \text { postrzeganie intencji } \\
\text { nadawcy } \\
\text { - poczucie własnej wartości } \\
\text { odbiorcy } \\
\text { - ewaluacja własnej pozycji } \\
\text { społecznej } \\
\text { - odniesienie do wyników } \\
\text { innych } \\
\text { - odniesienie do praktyki } \\
\text { społecznej }\end{array}$ \\
\hline
\end{tabular}

Źródło: opracowanie własne.

We wspomnianej wcześniej teorii sprawiedliwości J.S. Adams (1976) zwraca uwagę na fakt, że ludzie w ocenie swojej sytuacji posługują się „punktami odniesienia" - benchmarkami. Mogą się one odnosić do samego zainteresowanego, odpowiadającego m.in. na pytanie: „Czy mój dodatkowy wysiłek został lub zostanie sprawiedliwie wynagrodzony?". Mogą się odnosić do innych osób w formie odpowiedzi m.in. na pytania: „Czy mój wysiłek jest sprawiedliwie wynagradzany w porównaniu do wysiłku pracowników zajmujących to samo stanowisko, 
podobne stanowiska (np. w tym samym zespole), zróżnicowane stanowiska (np. w różnych zespołach), w różnych organizacjach (np. w organizacjach tej samej lub różnych branż)?”. Mogą się też odnosić do rozwiązań systemowych w formie m.in. odpowiedzi na pytania: „Czy system jest sprawiedliwy - czy właściwie uwzględnia właściwe kryteria?” oraz „Czy system jest stosowany sprawiedliwie i konsekwentnie?”. Uzupełnienie wcześniejszych rozważań na temat sprawiedliwości pozwala na praktyczne ukierunkowanie działań osób odpowiedzialnych za skonstruowanie, wyjaśnienie i stosowanie systemu wynagradzania. Przykładowo, znaczącym wyzwaniem okazuje się być wyjaśnienie całości systemu wynagradzania, a nawet szerzej - całości systemu zarządzania kapitałem ludzkim. Bez tego pracownicy często argumentują na rzecz wprowadzenia systemu akordowego (wynagradzającego efekty pracy), ale w połączeniu z utrzymaniem wynagrodzeń zasadniczych. Innym wyzwaniem jest poradzenie sobie ze szkodliwą praktyką GUS, uparcie publikującego informacje na temat średniego wynagrodzenia, z pełną świadomością, że większość osób zarabia poniżej tej kwoty, a ponadto bez dodatkowego wyjaśnienia dotyczącego wykorzystania tej wiedzy. Dochodzi przez to do żenujących scen, w których reprezentanci cenionych profesji publicznie przedstawiają swoje frustracje, prezentując swoje wpływy na konto z ostatniego miesiąca i porównując je do kwot uśrednionych, podawanych przez GUS w kwotach brutto, obejmujących wszystkie składniki wynagrodzeń, w tym takie, które są wypłacane rzadko (raz w roku lub raz na kwartał). Jeszcze innym, trudnym wyzwaniem jest wprowadzenie transparentności systemu wynagrodzeń, które jest konieczne, ale jednocześnie bardzo odległe od dzisiejszych standardów, gdzie „wynagrodzenia są poufne”. Praktyki te są jawnie szkodliwe, gdyż budzą zwykle nieuzasadnione przypuszczenia o łamaniu publicznie głoszonych zasad.

\section{Zróżnicowanie zasad sprawiedliwości}

Znaczenie kwestii systemu socjalnego i związanej z nim preferowanej zasad sprawiedliwości dystrybucyjnej można zilustrować prostym przykładem. Preferowane kryteria podziału (w obszarze sprawiedliwości rozdzielczej) różnią się w zależności od wieku i płci. W badaniu dotyczącym poczucia sprawiedliwości w zależności np. od roli, którą się pełni, wyraźnie to widać (tabela 3). W roli kierownika mężczyźni nieznacznie częściej opowiadali się za dominującą rolą w zespole; preferencja równego podziału rosła wraz z wiekiem - najbardziej skorzy do równego podziału byli respondenci mający więcej niż 45 lat.

Spośród respondentów, którzy w innych pytaniach deklarowali, że stać ich było na zaspokojenie wszystkich potrzeb, tylko 17\% przyznałoby $3 / 4$ puli na udzielenie 
premii sobie. Ci, którzy deklarowali, że stać ich jedynie na zaspokojenie podstawowych potrzeb, w największej liczbie (80\%) wybierali równy podział. Wśród respondentów deklarujących, że stać ich na wszystko, równy podział wybrało $60 \%$ osób. W grupie preferujących równy podział najwięcej było reprezentantów bezrobotnych, emerytów i studentów, natomiast w przypadku preferujących docenienie własnego wkładu - pracujących na umowę o dzieło i prowadzących własną działalność.

Tabela 3. Odpowiedzi na pytanie: „Wyobraź sobie, że kierujesz zespołem projektowym w firmie. Twój zespół liczy 4 osoby, łącznie z Tobą.

[...] Który sposób podziału premii w zespole wybierasz?" (w \%)

\begin{tabular}{|l|c|c|c|}
\hline Wyszczególnienie & $\begin{array}{c}\text { Wersja 1: 75\% dla } \\
\text { Ciebie, a 25\% dzielisz } \\
\text { po równo wśród reszty } \\
\text { zespołu, bo skoro } \\
\text { szef Tobie pozwolił } \\
\text { podzielić pieniądze... }\end{array}$ & $\begin{array}{c}\text { Wersja 2: 50\% premii } \\
\text { dla Ciebie, a drugą } \\
\text { połowę dzielisz po } \\
\text { równo wśród reszty } \\
\text { zespołu, bo w końcu } \\
\text { to Ty... }\end{array}$ & $\begin{array}{c}\text { Wersja 3: dzielisz się } \\
\text { nagrodą po równo } \\
\text { z reszą zespołu } \\
\text { i każdy włącznie z Tobą } \\
\text { otrzymuje dokładnie } \\
\text { taką samo kwotę }\end{array}$ \\
\hline Ogółem & 6,2 & 22,7 & 71,1 \\
\hline \multicolumn{4}{|c|}{ Płeć } \\
\hline Kobieta & 2,5 & 20,8 & 76,6 \\
\hline Mężczyzna & 10,2 & 24,9 & 65,0 \\
\hline & \multicolumn{3}{|c|}{ Wiek } \\
\hline 18-24 lata & 7,4 & 30,2 & 62,5 \\
\hline 25-34 lata & 7,0 & 35,4 & 57,6 \\
\hline 35-44 lata & 12,4 & 20,7 & 66,8 \\
\hline 45-54 lata & 4,0 & 20,1 & 75,9 \\
\hline 55 lat lub więcej & 3,2 & 14,1 & 82,7 \\
\hline
\end{tabular}

Uwaga: badanie przeprowadzono w dniach 29 kwietnia-3 maja 2017 r. na ogólnopolskiej próbie liczącej $N=1065$ osób, dobranej z Ogólnopolskiego Panelu Badawczego Ariadna metodą CAWI.

Źródło: opracowanie własne na podstawie wyników przeprowadzonego badania.

Zatem można zauważyć, że niektóre grupy wykazują stosunkowo niską akceptację wyższego wynagradzania osób piastujących stanowiska kierownicze. Oznacza to postrzeganie przełożonego jako „pierwszego pośród równych”. Jest to, oczywiście, zgodne zarówno z zaleceniami teorii, jak i praktycznymi wyzwaniami organizacji (np. koncepcja zarządzania turkusowego).

Innym przykładem zróżnicowania zasad jest poczucie własnej roli i podziału obowiązków np. ze względu na płeć. W badaniu przedstawiono sytuację, kiedy 
koleżanka spóźnia się do pracy, ponieważ musi odprowadzać dziecko do przedszkola. Kobiety w większym stopniu odpowiadają, że w związku z tym takie osoby powinny zarabiać mniej (twierdzi tak 28\% badanych, w tym 35\% kobiet i $20 \%$ mężczyzn). Wśród osób osiągających dochód na podstawie umowy o dzieło najwięcej twierdziło, że powinna zarabiać tyle samo.

Przedstawione wyniki potwierdzają, że poglądy na temat sprawiedliwości są kształtowane przez osobiste doświadczenia na bazie uwarunkowań kulturowych. Inne wyniki z tego badania potwierdzają $\mathrm{w}$ kontekście sprawiedliwości wyniki badań opinii CBOS wskazujących na istotną rolę rodziny w Polsce. Spóźnianie się do pracy w sytuacji, gdy punktualność jest istotna, oznacza nic innego niż konieczność wykonywania przez pracowników punktualnych obowiązków osób niepunktualnych. Jak się okazało w przeprowadzonym przez nas sondażu, może to być tolerowane przez współpracowników w sytuacjach, gdy trzeba okazać elastyczność wobec najważniejszych wyzwań i problemów rodzinnych. Jednakże spóźnianie się nie ma istotnego znaczenia w sytuacji, gdy liczy się efekt i jego osiągnięcie, co jest istotą umowy o dzieło. Wówczas wyzwania pozazawodowe nie odgrywają istotnej roli.

Dla pracodawców kreujących system wynagradzania wnioski płynące z przedstawionych wyników badań wydają się jednoznaczne - elastyczność względem poważnych problemów rodzinnych, a także kreowanie rozwiązań, które sprzyjają łączeniu wyzwań zawodowych i pozazawodowych są co najmniej dopuszczalne, a może nawet pożądane. Inaczej mówiąc, postrzeganie systemu jako sprawiedliwego nie stoi w sprzeczności z ułatwieniami względem potrzeb rodzinnych.

Wyniki cytowanego sondażu, obrazujące pewną pobłażliwość wobec spóźniających się współpracowników, dotyczyły nie tylko problemu odprowadzenia dziecka. O ile jesteśmy w stanie sobie zrozumieć czasowe niedomagania (np. koleżanka czy kolega jest po operacji szczęki i przedłuża sobie przerwę obiadową, gdyż potrzebuje więcej czasu na zjedzenie posiłku: $19 \%$ badanych uważa, że „taka osoba powinna zarabiać mniej niż ja”, a 53,9\% - że „tyle samo”, reszcie „trudno powiedzieć"), o tyle już nie wtedy, kiedy przerwa obiadowa jest wydłużana, ponieważ kolega czy koleżanka chce zjeść wegetariański obiad, a bar, gdzie takie dania są serwowane, znajduje się dosyć daleko od miejsca pracy, jest to bowiem indywidualny wybór danej osoby, a nie zdarzenie losowe. Zarówno wobec wegetarian, jak i innych obcych, spoza jakiegoś rodzaju istotnej wspólnoty, występuje brak symetrii w tolerancji wyrażający się niezgodą na takie same uposażenie - zwłaszcza w niektórych grupach. Wynika to wyraźnie z danych tablicy 4. Ciekawe, że wśród młodszych więcej jest osób, które chciałyby więcej zarabiać od osób, które w czasie pracy odbywają praktyki katolickie, a wśród starszych - praktyki muzułmańskie. 
Tabela 4. Wynagrodzenie w kontekście religii bliskiej i dalekiej (odpowiedzi w \%)

\begin{tabular}{|c|c|c|c|c|c|c|}
\hline \multirow{2}{*}{ Wyszczególnienie } & \multicolumn{3}{|c|}{$\begin{array}{l}\text { Kolega/koleżanka jest osobą } \\
\text { religijną, w czasie pracy w południe } \\
\text { i raz po południu modli się po } \\
20 \text { minut do Allaha na specjalnym } \\
\text { dywaniku }\end{array}$} & \multicolumn{3}{|c|}{$\begin{array}{c}\text { Kolega/koleżanka jest osobą bardzo } \\
\text { religijną i codziennie odrywa się od } \\
\text { pracy na kilka minut, by o godz. } 12 \\
\text { zmówić modlitwę Anioł Pański, zaś } \\
\text { o godz. } 15 \text { Koronkę do Miłosierdzia } \\
\text { Bożego }\end{array}$} \\
\hline & 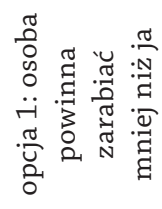 & 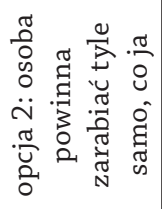 & 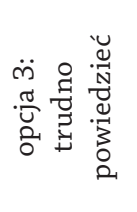 & 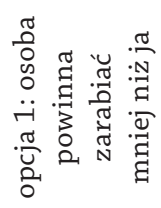 & 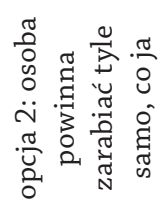 & 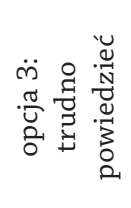 \\
\hline Ogółem & 48,4 & 22,4 & 29,3 & 44,6 & 28,8 & 26,6 \\
\hline \multicolumn{7}{|c|}{ Płeć } \\
\hline Kobieta & 55,9 & 18,3 & 25,8 & 50,7 & 23,6 & 25,8 \\
\hline Mężczyzna & 40,0 & 26,9 & 33,1 & 37,8 & 34,6 & 27,5 \\
\hline \multicolumn{7}{|c|}{ Wiek } \\
\hline 18-24 lata & 23,3 & 24,7 & 52,1 & 31,4 & 28,6 & 39,9 \\
\hline 45-54 lata & 57,8 & 14,7 & 27,5 & 38,6 & 33,2 & 28,2 \\
\hline \multicolumn{7}{|c|}{ Wykształcenie } \\
\hline Podstawowe & 45,1 & 20,0 & 34,9 & 40,8 & 27,0 & 32,2 \\
\hline Wyższe & 53,0 & 26,1 & 20,8 & 47,2 & 29,1 & 23,7 \\
\hline \multicolumn{7}{|c|}{ Zatrudnienie } \\
\hline Umowa o pracę & 50,3 & 25,8 & 23,9 & 41,4 & 32,5 & 26,0 \\
\hline $\begin{array}{l}\text { Własna } \\
\text { działalność }\end{array}$ & 33,5 & 50,4 & 16,1 & 46,6 & 41,0 & 12,4 \\
\hline Bezrobotny & 63,4 & 8,7 & 28,0 & 53,1 & 22,7 & 24,2 \\
\hline Student & 21,5 & 16,2 & 62,3 & 34,4 & 19,2 & 46,4 \\
\hline
\end{tabular}

Uwaga: badanie przeprowadzono w dniach 29 kwietnia-3 maja 2017 r. na ogólnopolskiej próbie liczącej $N=1065$ osób, dobranej z Ogólnopolskiego Panelu Badawczego Ariadna metodą CAWI.

Źródło: opracowanie własne na podstawie wyników przeprowadzonego badania.

Z tabeli 4 wynika, że elastyczność pracowników względem potrzeb religijnych oraz potrzeb wynikających z mniej istotnych niż rodzina i opieka nad krewnymi czynników może być źródłem poczucia niesprawiedliwości. Potrzeby religijne czy ideowe nie powinny być uwzględniane jako czynniki modyfikujące podstawowe wyzwanie sprawiedliwości (to samo wynagrodzenie za tę samą pracę, to samo wynagrodzenia za pracę wykonywaną $\mathrm{w}$ ten sam sposób). Potrzeby rodzinne i zdrowotne mogą natomiast być brane pod uwagę jako czynniki „pozytywnie dyskryminujące" osoby, które spotykają tego rodzaju wyzwania. Zatem w ramach 
sprawiedliwości rozdzielczej i proceduralnej respondenci stosują normy grupowe dotyczące ideologii, wspólnoty doświadczenia i podobieństwa, różnicują normy i zakres sprawiedliwości w zależności od roli, jaką pełnią w grupie. Role te różnią się w grupach w zależności od tego, które normy grupowe są ważniejsze.

\section{Narracje}

Z przedstawionych badań wynika, że grupy mają różne narracje dotyczące powinności wobec swoich członków i przynależnych im przywilejów. Ocena etyczna zależy więc od modelu narracyjnego, „obsługującego” dany obszar relacji, celów i ról społecznych, które przyjmują zaangażowane w nie jednostki.

Poręczną definicję narracji podaje J. Trzebiński (2002). Według tego autora narracja to schemat organizacji danych. Danymi tymi są bohaterowie działający w określonym celu, kierując się postępowaniem przynależnym ich rolom społecznym i wartościom. Narracja zatem jako pewien schemat poznawczy (Trzebiński, 2002, s. 23):

- $\quad$ wyznacza typ bohaterów historii dziejącej się w danej sferze;

- określa ich wartości, czyli pozytywne i negatywne dla bohaterów stany sfery świata, również stany hipotetyczne; ponadto, schemat narracyjny może generować modelowy repertuar intencji tych bohaterów oraz towarzyszące im plany realizacji;

- określa prawdopodobne komplikacje czekające bohaterów w momencie realizacji planów oraz inne ważne osoby, jak pomocnicy w dotarciu do celu oraz antagoniści;

- określa uwarunkowania i szanse przezwyciężenia trudności i realizacji intencji. W zależności od tego, kim jesteśmy w danej sytuacji, będą miały zastosowanie różne rodzaje zasad sprawiedliwości rozdzielczej. W izraelskim kibucu, będącym wspólnotą kolektywną, wszyscy mają równe wynagrodzenie niezależnie od produktywności. W firmach amerykańskich prezesi otrzymują tysiąckrotne wynagrodzenie pracownika (Deutsch, 2000).

Tak więc, biorąc pod uwagę cel i misję organizacji (tego, jaka opowieść nadaje jej sens), można akceptować przeciwstawne zasady sprawiedliwości wówczas, gdy celem jest: produktywność (liczy się zasada efektywności) lub spójność i dobre relacje (liczy się równość, zasada potrzeb, wspólnota). W przypadku gdy liczy się zasada potrzeb lub wspólnota, można nagradzać ofiarność innymi środkami niż wynagrodzenia pieniężne, nie tworząc sytuacji wygrany-przegrany.

Cele jednostek w kontekście pracy często zależą od klasy społecznej, ich roli społecznej względem innych i we wspólnocie oraz różnego rodzaju ideologii, którą wyznają. Inny jest stosunek do pracy rzemieślnika protestanta, inny wędrownego 
muzyka, inny osoby żyjącej z pracy na giełdzie, inny też założyciela wielopokoleniowej firmy rodzinnej.

Dla praktyki tworzenia systemów wynagradzania najistotniejsze wydają się uwarunkowania faktyczne, które dla różnych organizacji, a nawet dla różnych zespołów w ramach tej samej organizacji, mogą być inne.

Dla osób z zewnątrz wymagania wobec poszczególnych zespołów i stanowisk mogą się wydawać podobne lub nawet identyczne. Przykładowo, wydaje się, że od wszystkich pracowników należy oczekiwać kreatywności, rzetelności, odpowiedzialności, wiedzy czy nastawienia na współpracę. W rzeczywistości jednak w wielu zespołach wymóg współpracy może dotyczyć jedynie kreowania pozytywnej atmosfery w zespole, gdyż pracownicy w praktyce realizują indywidualne cele. W innych zespołach efekty poszczególnych osób nie dają się wyodrębnić, a podstawowa wartość powstaje dzięki synergii. Pozwala to na ustalenie odpowiedniego, zobiektywizowanego modelu sprawiedliwości, a w ślad za tym - na przyciąganie do konkretnych zespołów osób o odpowiednich postawach i oczekiwaniach. System wynagradzania może wówczas pełnić rolę zarówno przyciągającą, jak i odpychającą. Tego rodzaju mechanizmy jednoznacznie pomagają w wyborze ścieżki zawodowej lub modyfikacji własnych przekonań. System wynagradzania promujący równość, której potrzeba wynika z rzeczywistej potrzeby współpracy, powinien zniechęcać osoby nastawione na indywidualne efekty i ceniące wysoki poziom ryzyka.

\section{Nieuniwersalne procedury podziału}

W teorii i praktyce zarządzania wynagrodzeniami istnieją w niektórych przypadkach już ponad stuletnie doświadczenia w różnicowaniu wynagrodzeń. Koncepcje różnicowania stanowisk pracy (wartościowanie stanowisk pracy) mogą kłaść inny nacisk na poszczególne kryteria oceny wartości pracy (Juchnowicz, Sienkiewicz, 2006). Niektóre z rozwiązań bardziej promują te elementy trudności pracy, które są własnością pracownika i czymś „wnoszonym do pracy” (input), np. wiedza zawodowa/wykształcenie. Inne metody kładą większy nacisk na sam proces pracy (process), np. rozwiązywanie problemów, odpowiedzialność. Jeszcze inne metody szczególnie doceniają efekty (output), np. wpływ na rezultaty organizacji. W ramach metod wartościowania są także uwzględniane inne kryteria, np. monotonia czy szkodliwe warunki pracy, ale mają one coraz mniejsze znaczenie.

$Z$ badania opinii, przeprowadzonego przez zespół badawczy złożony z przedstawicieli Szkoły Głównej Handlowej w Warszawie i Uniwersytetu Warszawskiego w ramach wspomnianego już grantu pt. Sprawiedliwość Wynagrodzeń, wynika, że 
wyższe wykształcenie badanych pozytywnie korelowało z deklaracją, iż efektywność pracy powinna wpływać na zarobki. Może się to wiązać z większą kontrolą własnej pracy w tej grupie - w przypadku ekspedienta w kiosku czy ochroniarza sklepowego w danej jednostce czasu trudno realnie mówić o zwiększeniu ich efektywności, która byłaby zależna od nich samych. Odwrotnie do wykształcenia mają się wyniki w kwestii wieku - im starsi respondenci, tym większy odsetek osób, które nie chciałyby uzależniać wynagrodzenia od efektywności.

Podobna zależność występuje w przypadku wpływu na wysokość zarobków większej liczby obowiązków, wypełniania zadań szczególnie ważnych dla firmy - można zaryzykować twierdzenie, że dotyczy to poczucia kontroli i sprawczości w pracy.

Z badania wynika, że większość respondentów dostrzega ostateczny cel pracy, jakim jest osiąganie rezultatów (wyników pracy) i wskazuje konieczność łączenia wynagrodzeń z efektami (rysunek 1). Jednocześnie przeprowadzone badanie ujawnia osoby, które nie są w stanie zrozumieć tego rodzaju związku lub, rozumiejąc go doskonale, oczekują niesprawiedliwych z perspektywy rezultatów podziału korzyści. Mówiąc inaczej, są to osoby, które deklarują chęć udziału w sukcesach odniesionych przez innych. Częściej są to osoby o niższym wykształceniu i niższych dochodach. Zdumienie może budzić jednak oczekiwanie opracowania takiego systemu wynagradzania, który transferowałby korzyści od pracowników efektywnych do nieefektywnych.

W swoich odpowiedziach respondenci z wykształceniem podstawowym byli w mniejszej liczbie skłonni uzależniać zarobki od efektywności (rysunek 2).

Druga sprawa wiąże się z poczuciem roli społecznej. W sytuacji gdy podmiotem jest rodzina (pracuje się na rodzinę, jest się żywicielem rodziny, pracuje się, gdyż ma się na utrzymaniu dzieci itp.), wówczas praca daje satysfakcję w kontekście wypełniania danej roli społecznej, a niekoniecznie w kontekście samego działania. Wtedy kategorie indywidualistyczne - czyli to, czy się lubi swoją pracę czy nie, czy ma się możliwości rozwoju itp. - nie mają zastosowania, a przynajmniej mają niższy priorytet. Pośrednio potwierdzają to badania dr H. Kinowskiej i prof. dr hab. M. Juchnowicz (wykonane w ramach wspomnianego projektu badawczego pt. Sprawiedliwość wynagradzania), według których dopiero od pewnego poziomu dochodu respondenci wskazywali, że do czerpania satysfakcji z pracy potrzeba im także dobrych relacji z przełożonym.

Wracając do sytuacji rodzinnej jako czynnika determinującego sprawiedliwość rozdzielczą, jest ona postrzegana jako szczególnie istotna w grupie osób z niskim wykształceniem i niskimi dochodami (a więc w grupach, w których praca jest ściśle związana $\mathrm{z}$ rolą społeczną utrzymującego rodzinę, a nie np. ze spełnieniem zawodowym) - rysunek 3. Tymczasem czynnik sytuacji rodzinnej jako istotny 


\section{Rysunek 1. Odpowiedzi na pytanie: „Proszę powiedzieć, na ile według Pana/Pani} wyniki pracy powinny mieć wpływ na wynagrodzenie?”

OGÓ£EM

Nie wiem\trudno powiedzieć $0 \%$

Zdecydowanie powinny mieć wpływ

Ani powinny, ani nie powinny mieć wpływu

Raczej nie powinny mieć wpływu Zdecydowanie nie powinny mieć wpływu
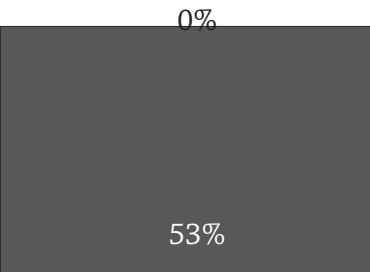


\section{Rysunek 2. Rozkład wyboru odpowiedzi „To, że pracują bardziej efektywnie} (są w stanie w tym samym czasie zrobić więcej)" na pytanie: "Co według Pana/Pani powinno wpływać na fakt, że osoby na tym samym stanowisku powinny zarabiać więcej od innych?”

\section{OGÓŁEM}

Nie wiem $\backslash$ trudno powiedzieć

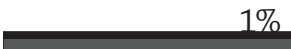

Zdecydowanie się zgadzam



Raczej się zgadzam

Ani się zgadzam, ani się nie zgadzam

Raczej się nie zgadzam Zdecydowanie się nie zgadzam
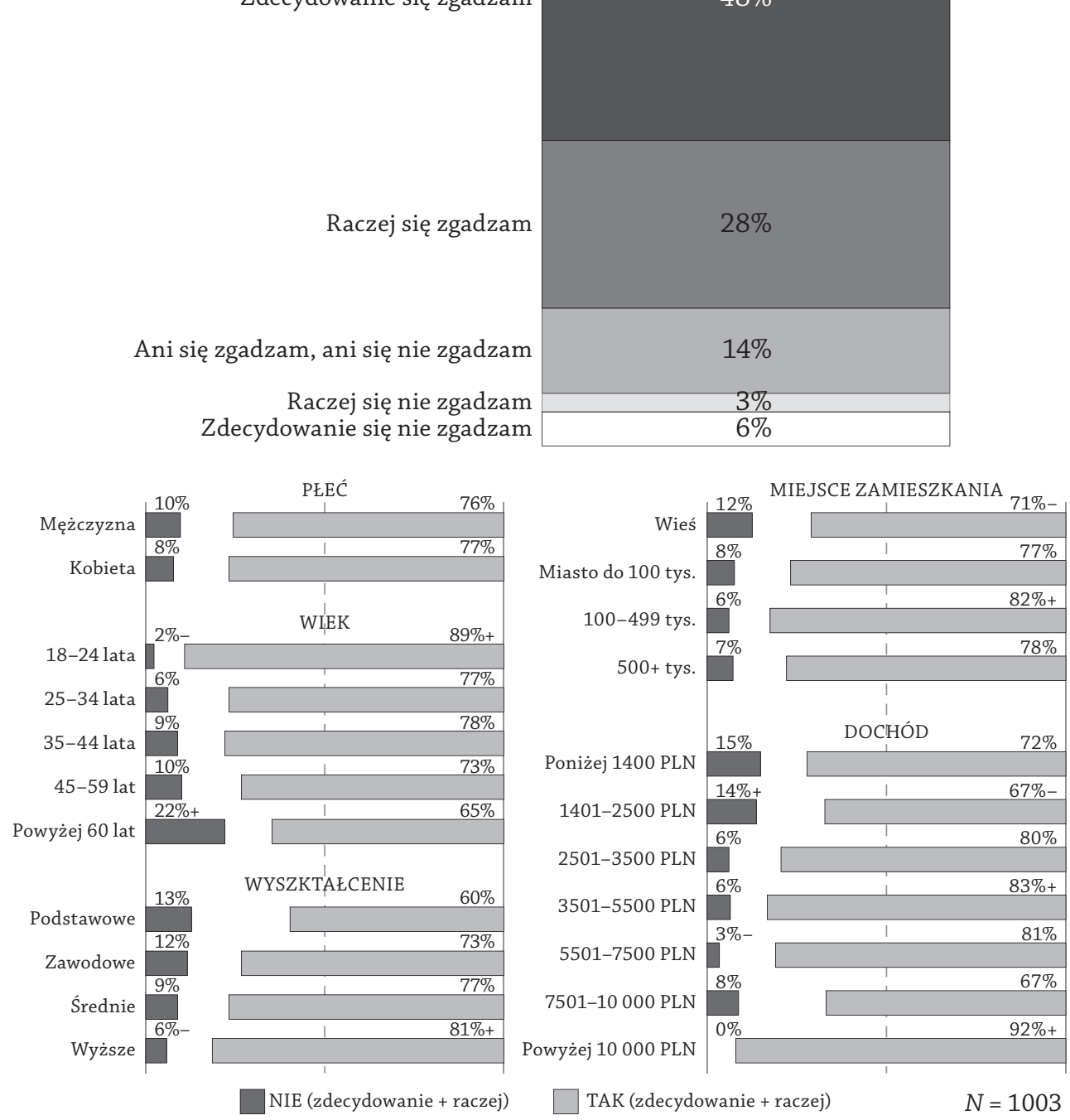

Uwaga: +\- różnice statystycznie w stosunku do wszystkich respondentów istotne na poziomie 95\%.

Źródło: badanie Kantar MaillwardBrown. 


\section{Rysunek 3. Odpowiedzi na pytanie: „Czy Pana/Pani zdaniem zarobki osób na tym} samym stanowisku powinny być wyższe, jeżeli są jedynymi żywicielami rodziny?"
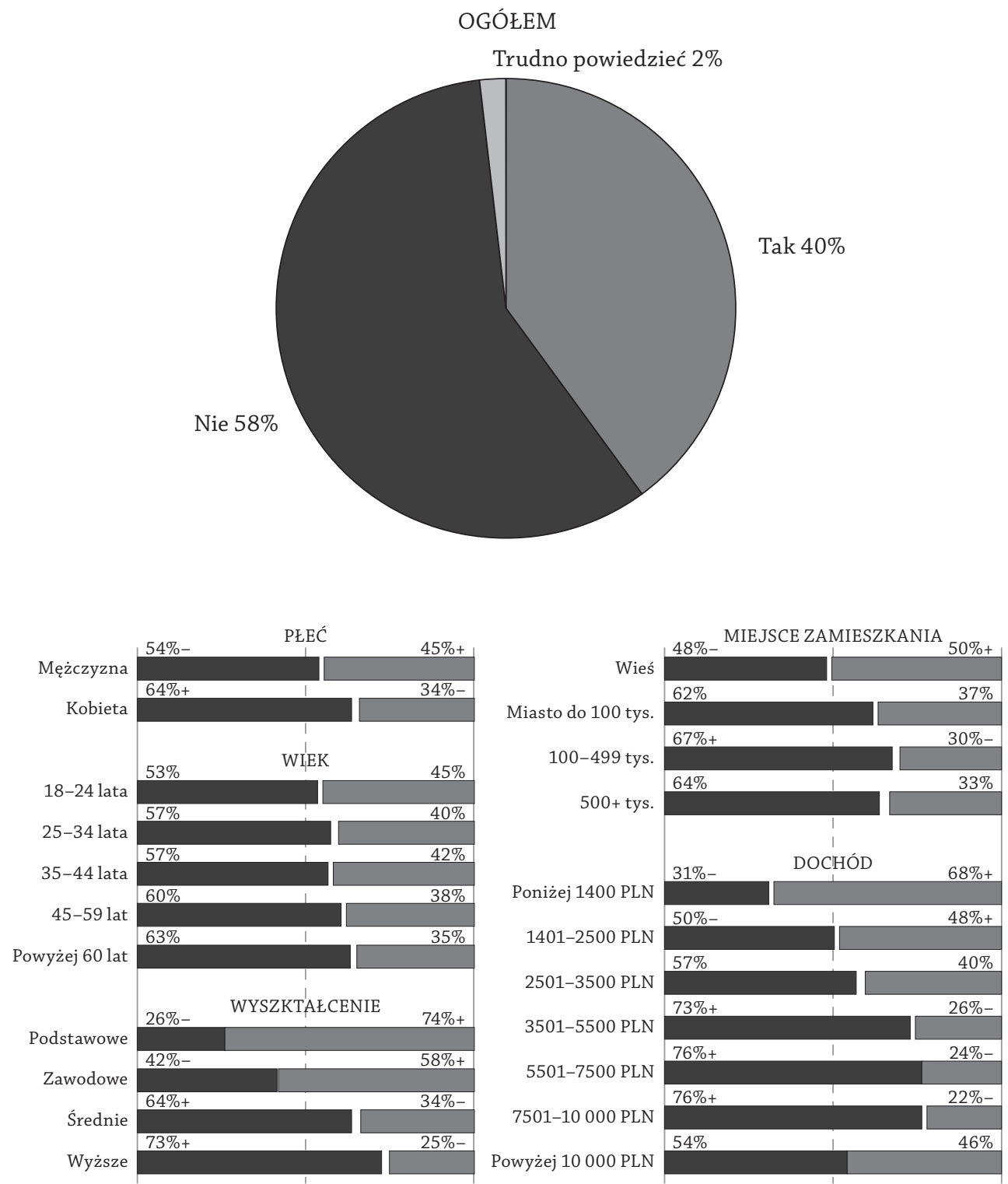

$N=1003$

Uwaga: +\- różnice statystycznie w stosunku do wszystkich respondentów istotne na poziomie 95\%.

Źródło: badanie Kantar MaillwardBrown. 
Rysunek 4. Odpowiedzi na pytanie: „Zdarza się, że wynagrodzenie składa się z części stałej, zmiennej i świadczeń dodatkowych. Proszę teraz pomyśleć o części stałej wynagrodzenia i powiedzieć, czy [...] sytuacja rodzinna powinna mieć wpływ na jej wysokość?"
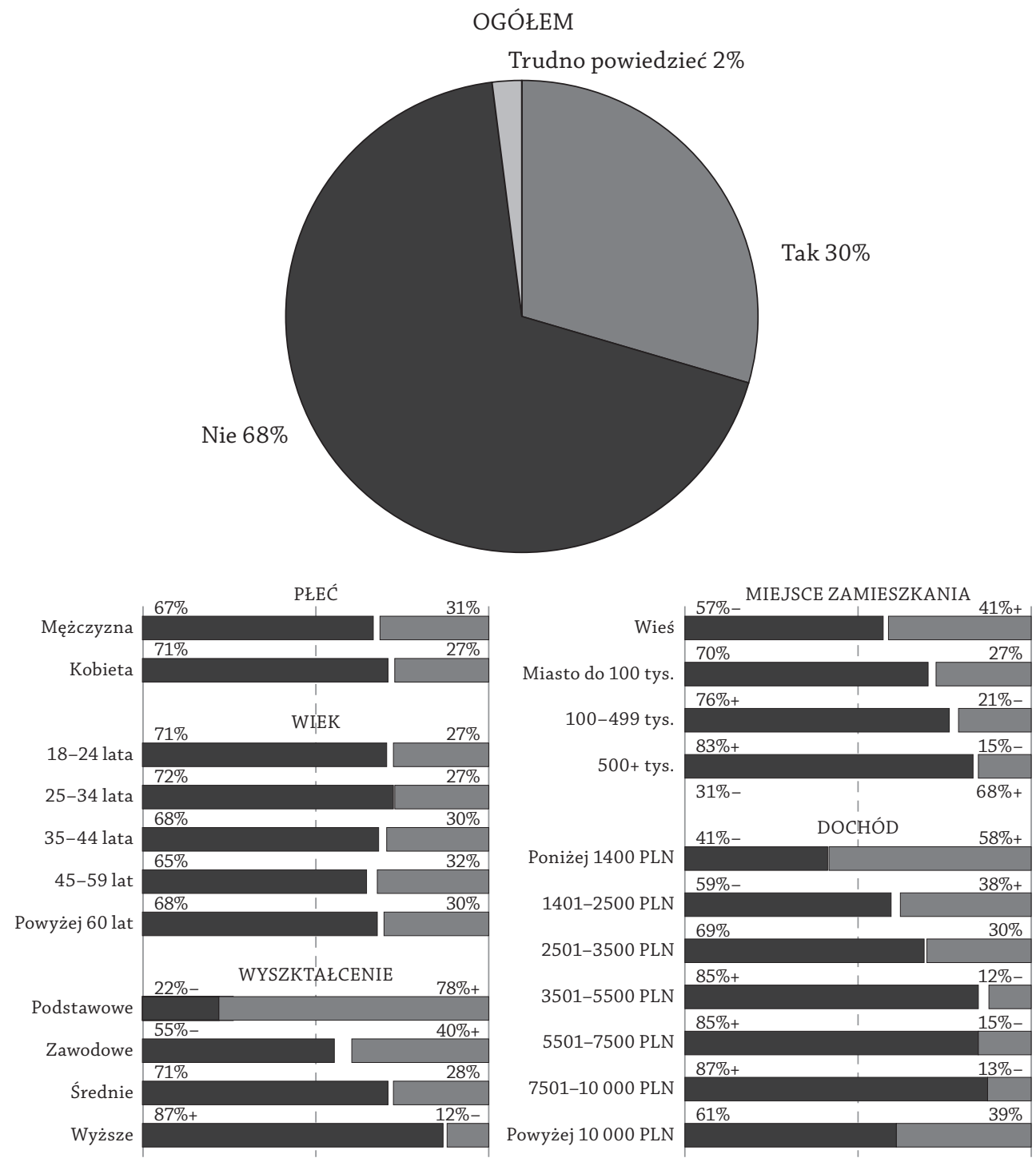

$N=1003$

Uwaga: +\- różnice statystycznie w stosunku do wszystkich respondentów istotne na poziomie 95\%. Źródło: badanie Kantar MaillwardBrown. 
Rysunek 5. Odpowiedzi na pytanie: „Proszę teraz pomyśleć o części zmiennej wynagrodzenia (premiach) i powiedzieć, czy [...] sytuacja rodzinna powinna mieć wpływ na jej wysokość?"

\section{OGÓEEM}



Tak 33\%


$N=1003$

Uwaga: $+\backslash$ - różnice statystycznie w stosunku do wszystkich respondentów istotne na poziomie 95\%.

Źródło: badanie Kantar MaillwardBrown. 


\section{Rysunek 6. Odpowiedzi na pytanie: „Wynagrodzenie powinno się składać z...”}

\section{OGÓŁEM}

Trudno powiedzieć Tylko z części zmiennej

Z części stałej i zmiennej (czyli z premii \prowizji\nagród)
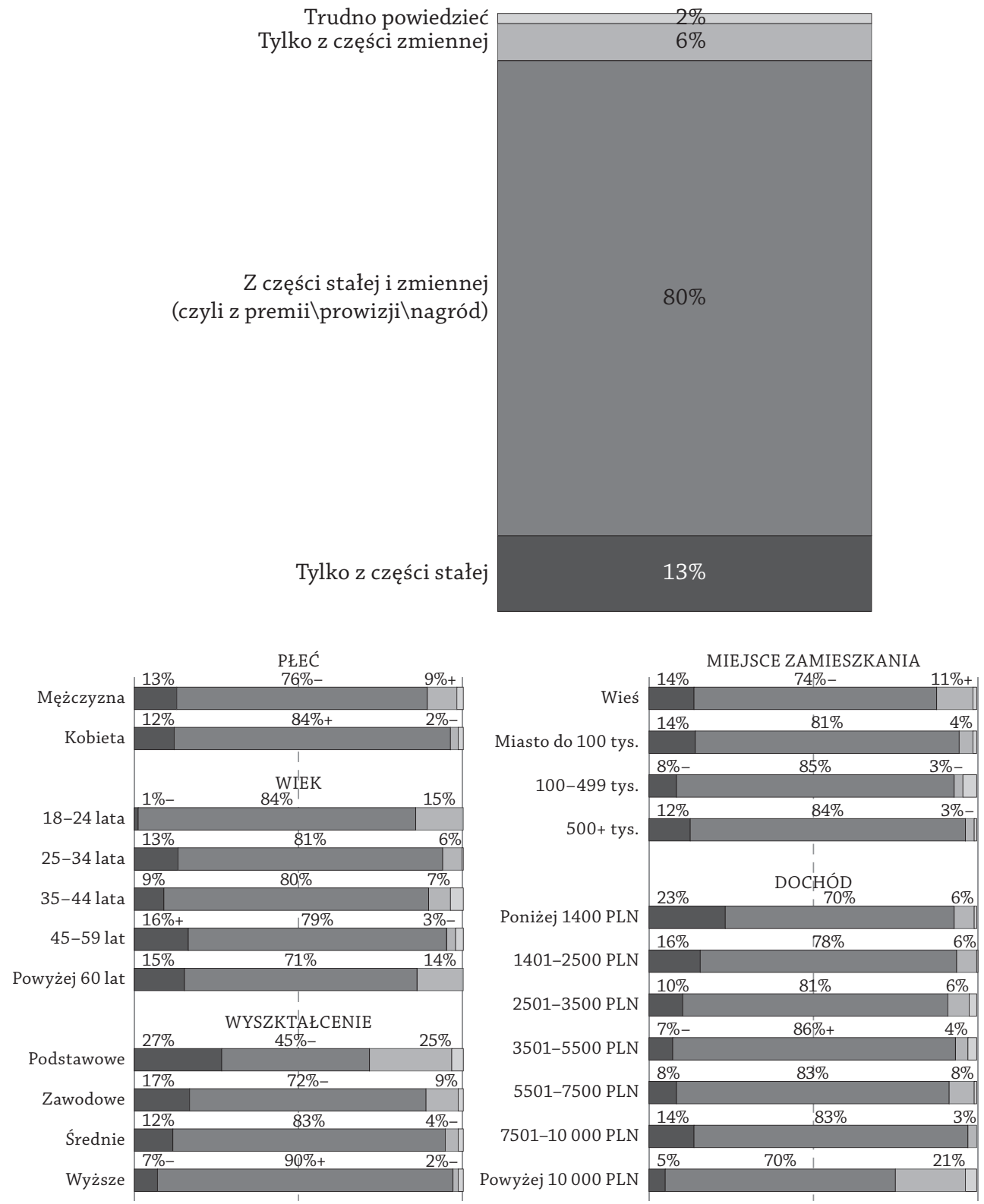

$N=1003$

Uwaga: +\- różnice statystycznie w stosunku do wszystkich respondentów istotne na poziomie 95\%.

Źródło: badanie Kantar MaillwardBrown. 
deklarują także respondenci z wysokimi dochodami, co może się wiązać z bardzo dużymi wydatkami na dzieci w tej klasie społecznej (np. wysokimi obowiązkami alimentacyjnymi).

Co ciekawe, wśród osób deklarujących powiązanie wynagrodzenia z sytuacją rodzinną dotyczy to zarówno stałej, jak i zmiennej części wynagrodzenia (rysunki 4 oraz 5). Przy tym ponad 1/4 osób z wykształceniem podstawowym uważa, że część zmienna jest niepotrzebna (rysunek 6).

W opinii większości respondentów sytuacja rodzinna powinna wpływać na wysokość uzyskiwanych wynagrodzeń. W badaniach nie poruszono kwestii źródeł finansowania tego rodzaju zróżnicowania. Z perspektywy opłacalności zatrudnienia, osoby mające silną motywację do pracy są szczególnie cenne. Zachowanie prostego mechanizmu logicznego wskazującego, że osoby o silnej motywacji (np. wynikającej z uwarunkowań rodzinnych) powinny mieć silną motywację zarówno do wysokiej efektywności, jak i do inwestycji w siebie, co owocowałoby wyższymi wynagrodzeniami, wydaje się w pełni uzasadnione. Jednakże pominięcie wysokiej efektywności i chęci rozwoju zawodowego może być uznane za motywowanie finansowe do prezentowania określonych zachowań w sferze prywatnej jako ekwiwalentu działań zawodowych. W takim wypadku nie sposób nie zauważyć, że dla wielu osób, w tym zwłaszcza dla osób o niskim poziomie wykształcenia, uzyskanie „trudnej sytuacji rodzinnej” jest o wiele łatwiejsze niż pozyskanie kompetencji i wiążącą się z tym wysoką efektywność pracy.

\section{Narracyjne modele dotyczące sprawiedliwości}

Bazując na przedstawionych rozróżnieniach i różnicach w deklaracjach, można wyróżnić kilka narracji, w których będą „zanurzone” kryteria związane z czynnikami sprawiedliwego wynagrodzenia, dotyczące sprawiedliwości rozdzielczej oraz proceduralnej.

Można założyć, że w każdej kulturze modelowe przypadki będą obsługiwać różne metafory i narracje, w których ramach dane zachowania będą oceniane pozytywnie lub nie. Przykładowo, metafora wyścigu, w którym liczy się najlepszy, będzie nadszarpywała spójność relacji organizacji bazujących na współpracy (jak spółdzielnia), ale będzie korzystnie wpływać na wyniki zorientowanych na sukces jednostek, jak maklerów. Kto nie wytrzymuje, jest sam sobie winny i powinien poszukać innej możliwości zarobkowania. Metafora rodziny będzie sprzyjać stabilnej jakościowo produkcji, w której liczy się poczucie bezpieczeństwa. Członkowie zauważają swoje potrzeby i dbają o nie, nagradzają się także niefinansowo (wycieczki, dni wolne, świadczenia zdrowotne i opieka). Kto nie wytrzymuje, 
ten przechodzi na inne stanowisko lub ma inaczej zorganizowaną pracę. Metafora ogrodu będzie obsługiwać organizację nastawioną na służbę, której celem jest rozwój danego obszaru, w której liczy się różnorodność doświadczeń oraz sposobu działania, w której bardziej od zysku będą cenione wartości działania i etos.

Takich metafor jest więcej i stanowią one zapewne system otwarty. Przykładowo, w badanej grupie respondentów w wieku 18-24 lata najbardziej - w porównaniu z innymi grupami - są cenione niezależność i robienie tego, co się lubi, a także atmosfera i kontakt z ludźmi. Jest to nowy trend, nastawiony na zbieranie doświadczeń, a nie na stały, zaplanowany rozwój kariery i pięcie się po jej szczeblach.

Aby posegregować czynniki mające wpływ na postrzeganie sprawiedliwości i nadawanie priorytetu jednemu $\mathrm{z}$ nich, poniżej zaproponowano model metafor oparty na systemie bogów olimpijskich. Jest to zarówno inspiracja powszechnym w marketingu modelem archetypów opartych na dominującej potrzebie (Mark, Pearson, 2001), jak i podejściem do zarządzania zaproponowanym przez M. Kosterę (2008, s. 9-12). Kolumny z prawej strony tabeli 5 zawierają główną zasadę, która wyznacza kryteria sprawiedliwości (np. zasada konkurencji lub równości) i kryterium rozdzielcze (co ostatecznie liczy się przy ustalaniu wysokości wynagrodzenia - według jakiej procedury wyznacza się tę wysokość). Następnie mamy kolumnę z etykietą tej zasady, której personifikacją jest jeden z bogów olimpijskich. Kolejna kolumna to kluczowe czynniki, które przy tak sformułowanych zasadach należy brać pod uwagę w procedurze sprawiedliwego wynagradzania. Kolejna kolumna odnosi się do systemu zbudowanego na takich zasadach i przedstawia kluczowe rozwiązania dotyczące wynagrodzeń. Dwie ostatnie kolumny - po lewej stronie - dotyczą komunikacji i reakcji na łamanie tych zasad. A więc kolumna „Co budzi poczucie niesprawiedliwości” jest opozycją dla kolumny „Główne czynniki w procedurze sprawiedliwego wynagradzania” i dotyczy kwestii komunikacji przy tak ustalonych zasadach. Ostatnia kolumna to źródła zawiści, a więc czynniki, które sprawiają, że inne grupy nie uznają takich kryteriów wynagrodzenia lub postrzegają wysokość uposażeń jako niesprawiedliwe, niewłaściwe, niesłuszne. To również kwestie z obszaru komunikacji, a zwłaszcza postrzegania strategicznej roli różnych zespołów w organizacji.

Z tabeli 5 wynika, jak różne czynniki związane z kluczowym kryterium mogą być akceptowane jako sprawiedliwe w obszarze sprawiedliwości rozdzielczej. Każdy z podziałów wynika z określonej narracji i obsługującej ją metafory. Podział organiczny będzie eksponował sprawiedliwość informacji, podział wspólnotowy - proces i interakcje, równy podział skupia się na kryterium alokacji, a wynagrodzenia komunikowane w metaforach wyścigu będą dotyczyły głównie jasnych reguł wygranej. Niektóre badania potwierdzają, że osobom o większej skłonności 


\begin{tabular}{|c|c|c|c|}
\hline 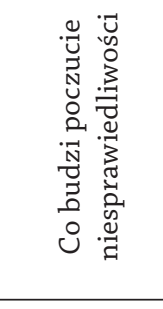 & 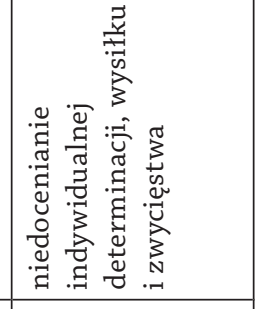 & 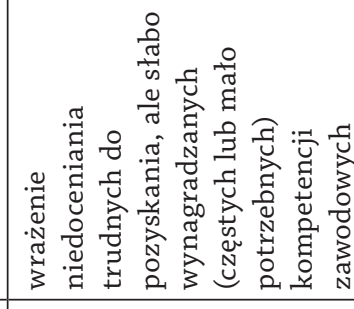 & 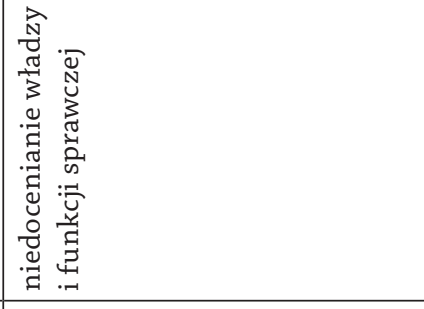 \\
\hline 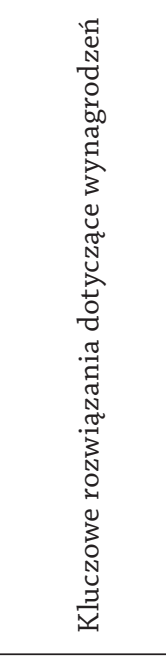 &  & 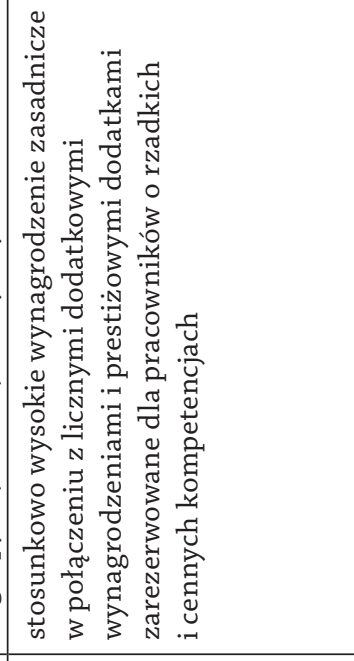 & 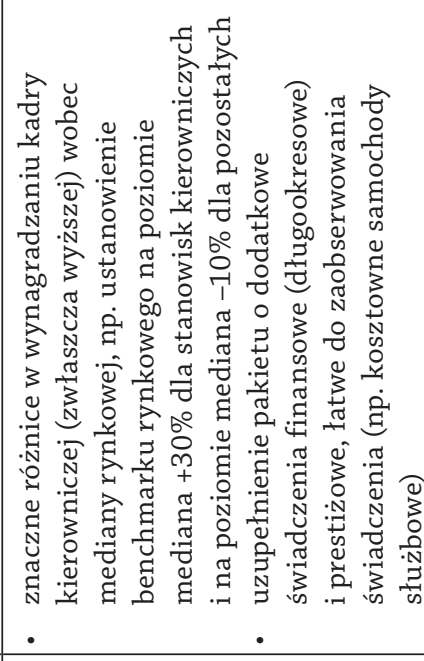 \\
\hline 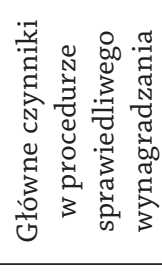 & 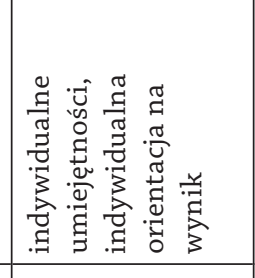 & 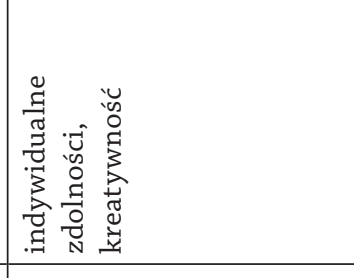 & 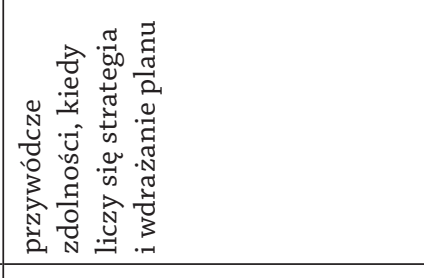 \\
\hline 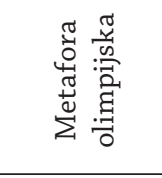 & $\begin{array}{l}\mathscr{U} \\
\ddot{Z}\end{array}$ & 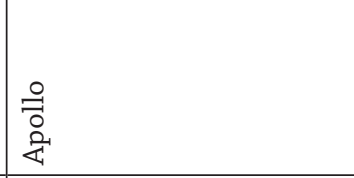 & \begin{tabular}{|c} 
J్ \\
N
\end{tabular} \\
\hline 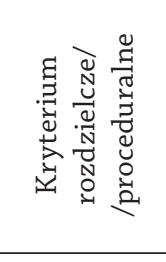 & 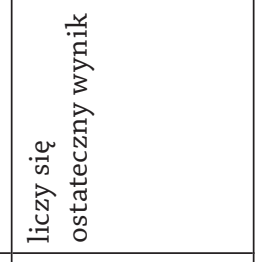 & 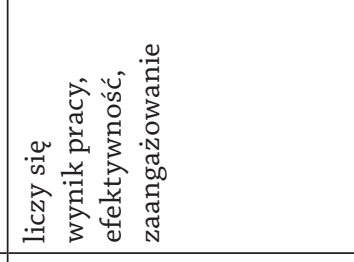 & 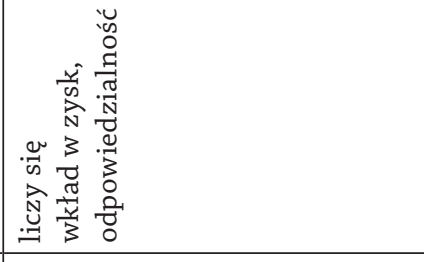 \\
\hline  & 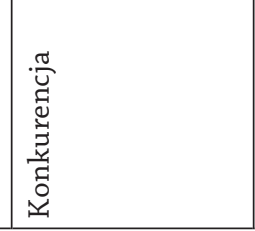 & 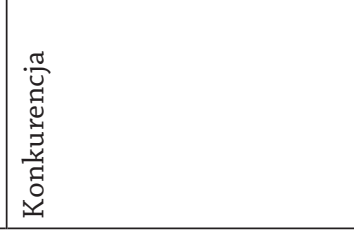 & 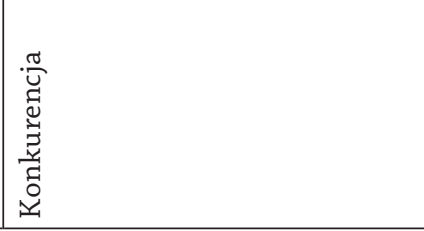 \\
\hline
\end{tabular}




\begin{tabular}{|c|c|c|c|}
\hline 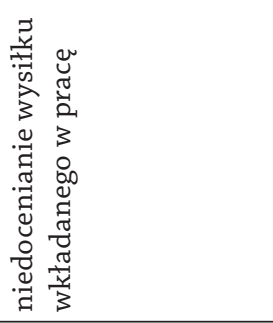 & 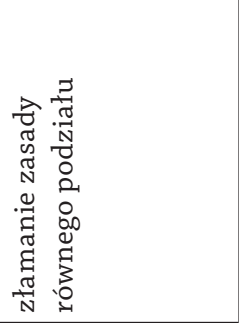 & 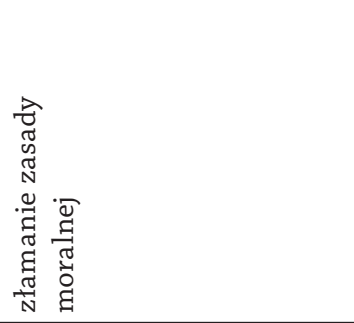 & 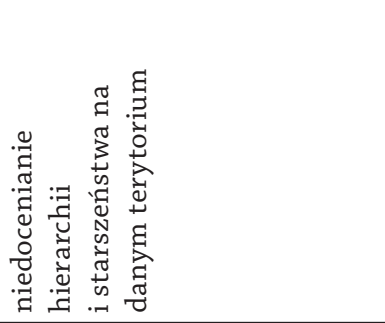 \\
\hline 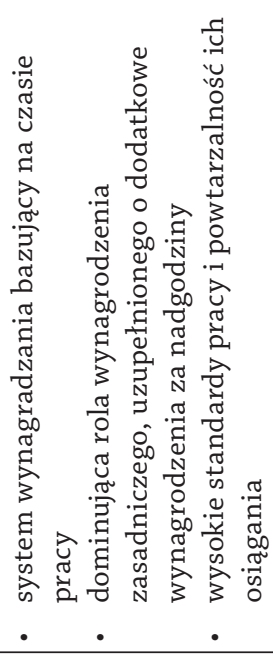 & 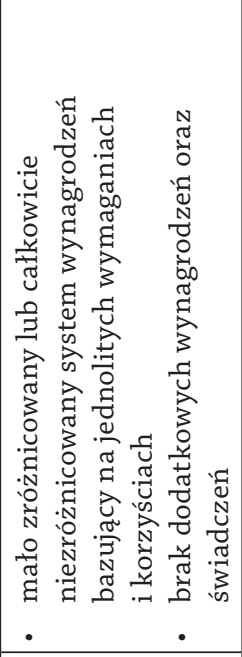 & 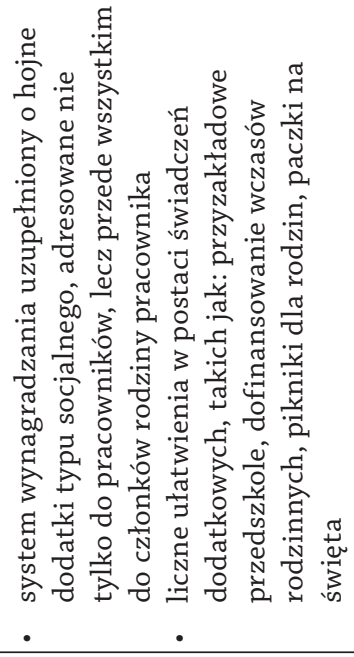 & 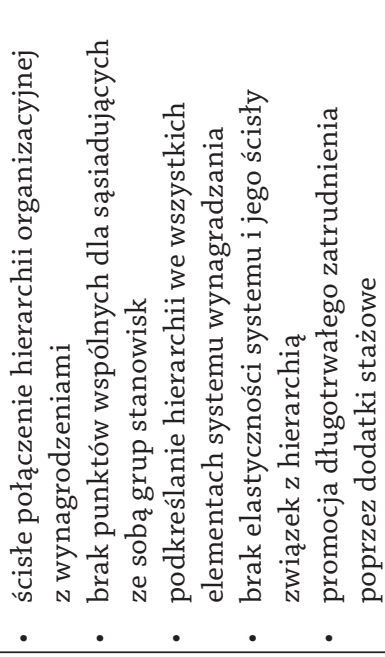 \\
\hline 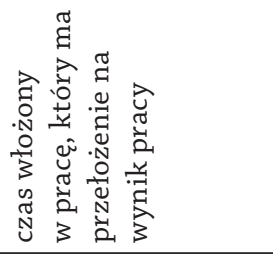 & 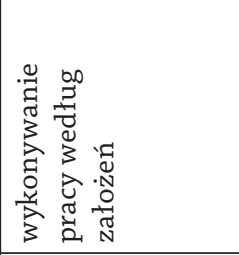 & 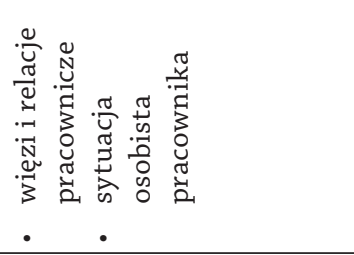 & 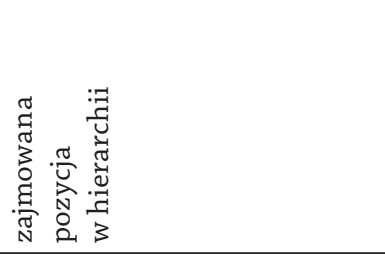 \\
\hline & $\begin{array}{l}0 \\
0 \\
0 \\
0 \\
\text { பี } \\
\end{array}$ & 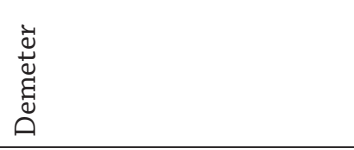 & \\
\hline 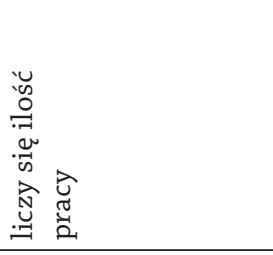 & 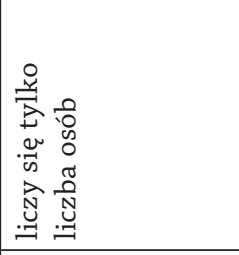 & 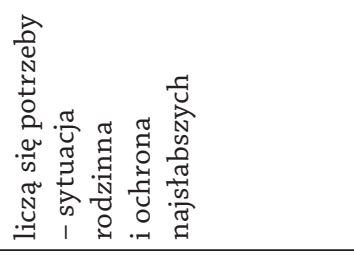 & 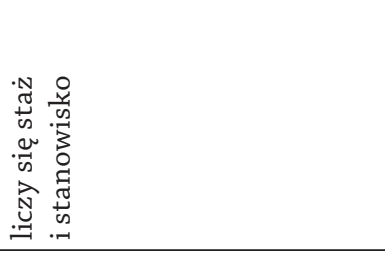 \\
\hline  & 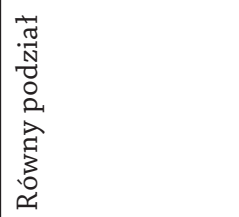 & 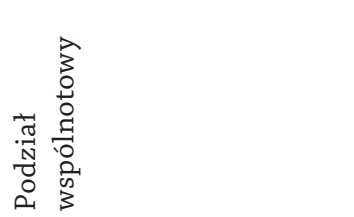 & 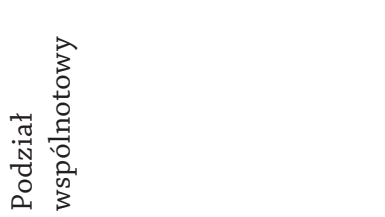 \\
\hline
\end{tabular}




\begin{tabular}{|c|c|c|c|}
\hline 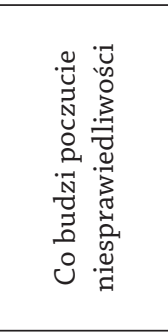 & 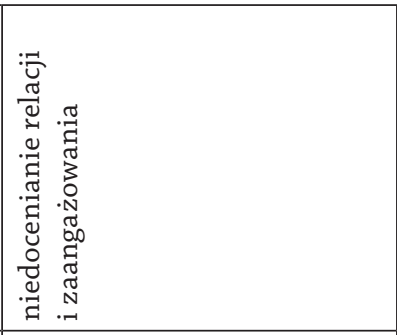 & 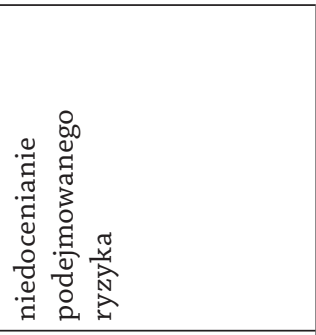 & 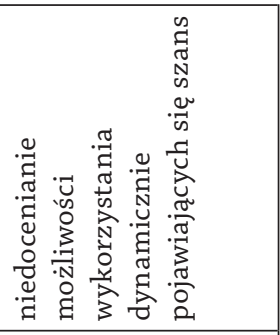 \\
\hline 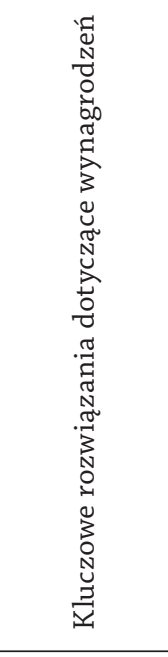 & 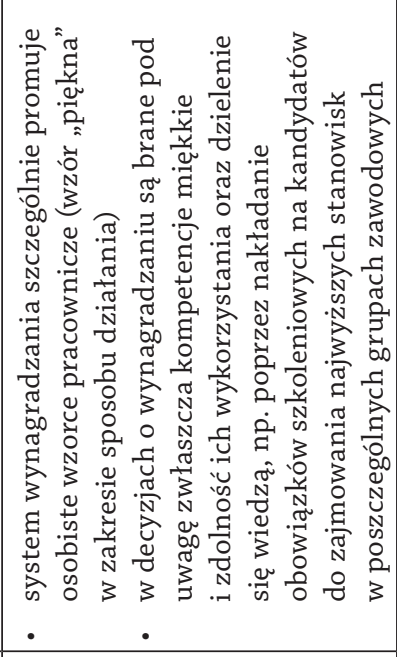 & 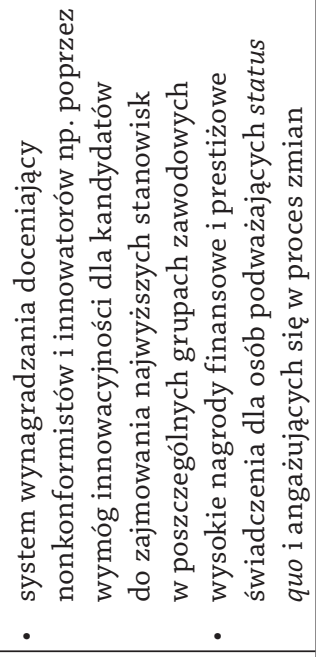 & 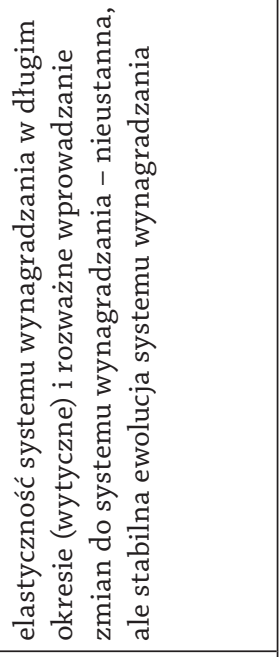 \\
\hline 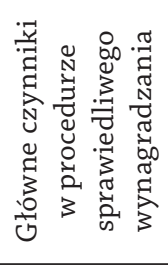 & 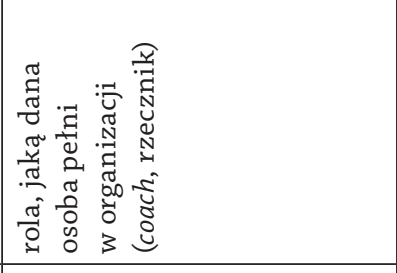 & 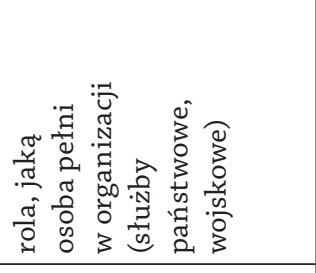 & 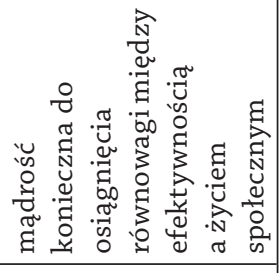 \\
\hline 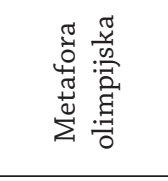 & 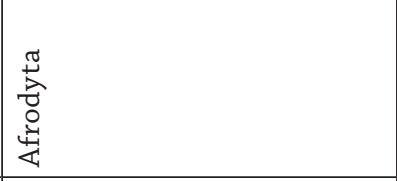 & 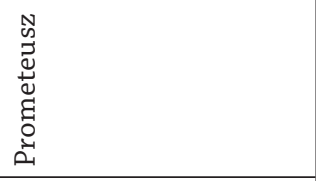 & 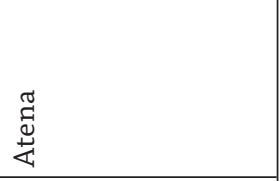 \\
\hline 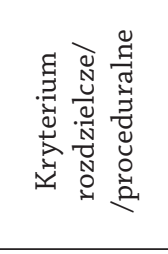 & 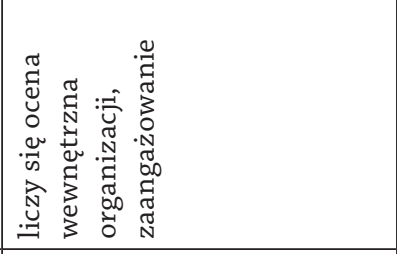 & 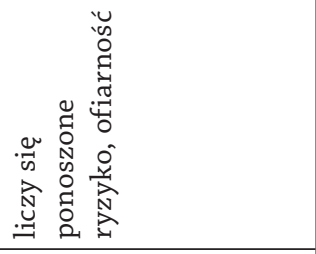 & 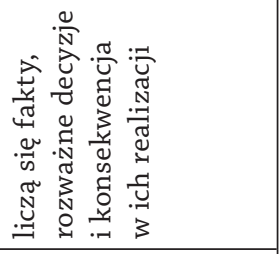 \\
\hline 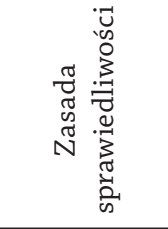 & 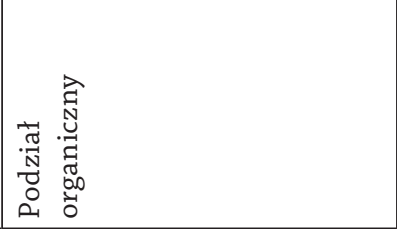 & 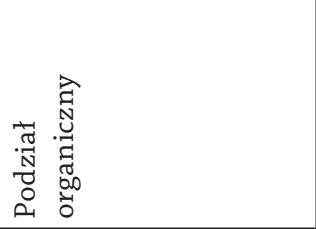 & 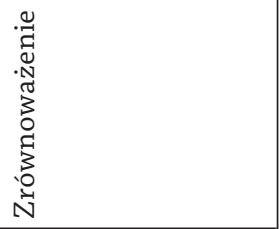 \\
\hline
\end{tabular}


do ryzyka mniej odpowiadają sztywne ramy sprawiedliwości (Desai, Sondak, Diekmann, 2011).

Narracje o pracy i roli jednostki w pracy uzasadniają określone sposoby działania i wpisane w nie nierówności jako słuszne i stanowiące element "gry społecznej” (Goffman, 2008). Narracja obsługująca daną pracę, z zawartym w niej zestawem wartości, jeśli jest akceptowana, ustawia priorytet omówionym wcześniej czynnikom wpływającym na poczucie sprawiedliwości wynagrodzenia (dystrybucji, procesu, interakcji czy wymiarom interakcji - interpersonalnemu i informacyjnemu).

\section{Podsumowanie}

Etyka uniwersalistyczna, wynikająca z jednego absolutnego źródła, prowadzi do obiektywistycznego ujęcia sprawiedliwości. W praktyce ujęcie to bywa niedostosowane do celów firmy, osób angażujących się w dane działania, a także charakteru pracy i związanej z nim wydajności danych działań. Grecy potrzebowali wiele bóstw, które niejako opiekowały się poszczególnymi działaniami lub dotyczyły funkcjonowania w danych rolach społecznych. Czas wojny (także rynkowej), czas opieki (także społecznej), czas sądu (także gospodarczego), czas pracy rzemieślniczej i pracy twórczej wiązały się z archetypem reprezentującym specyficzne preferencje działania. W związku z tym można przyjąć, że niektóre obszary, jak sport, wojna czy ogrodnictwo, będą wymagać stosownych czynników sprawiedliwego wynagradzania.

Kryterium, jakim posłużono się przy konstruowaniu modeli narracyjnych, było istnienie praktycznych potrzeb organizacji w Polsce.

Modele Aresa i Apolla polecamy dynamicznym organizacjom zastawionym na szybki wzrost, przy czym ten drugi zdaje się pasować przede wszystkim do firmy wysokich technologii i innych organizacji, które szybkiego wzrostu upatrują w posiadaniu pracowników o unikalnych i poszukiwanych na globalnym rynku kompetencjach.

Model Zeusa wydaje się pasować do sytuacji wielu firm, które gwarantują stabilność działania dzięki utrzymaniu w organizacji znakomitych organizatorów i przywódców odpowiedzialnych m.in. za upraszczanie i standaryzację działań na niższych stanowiskach, dzięki czemu wysoka fluktuacja nie jest istotnym kłopotem.

Model Hefajstosa i Chronosa powinny rozważyć wszystkie organizacje, w których realny awans jest utrudniony, a prace są wystandaryzowane. To rozwiązanie polecamy także firmom, które pomimo licznych prób nie stworzyły systemu awansowania, który byłby czymś innym niż zmianą sposobu nazywania stanowisk wraz z upływającym czasem. 
Model Demeter wydaje się pożądany przez wielu pracowników w Polsce poprzez jego zgodność z wyznawanymi wartościami. Jest on także korzystny w długim okresie i pozytywnie wpływa na długookresowy zwrot z inwestycji, zwłaszcza gdy nacisk na wsparcie rodziny jest wzmocniony odpowiednimi relacjami rodzinnymi wewnątrz organizacji i promocją wysokiej efektywności zespołowej.

Model Hery to model bardzo zalecany wszystkim organizacjom, które z racji obowiązującego prawa nie mogą z niego nie skorzystać, tj. niemal wszystkim organizacjom publicznym.

Model Afrodyty z kolei stanowi odpowiedź na potrzebę tworzenia i dzielenia się wiedzą w pozytywnej atmosferze, a model Prometeusza to w praktyce promocja innowacji, ciągłego usprawniania i wyprzedzania konkurencji poprzez proaktywne działania.

Model Ateny, który może się wydawać najbardziej uniwersalnym z zaproponowanych podejść, w praktyce nie nadaje się do stosowania w większości organizacji.

Korzystnym rozwiązaniem jest wykorzystanie konkretnego modelu narracyjnego do konkretnej grupy zatrudnionych i wprowadzenie zróżnicowanej narracji o wynagrodzeniach i wynikających z niej uzasadnień np. dla pracowników sprzedaży i pracowników produkcji czy księgowości. Rozwiązaniem trudniejszym jest próba skonstruowania spójnego rozwiązania dla całej organizacji, w której pracownicy w swym postrzeganiu sprawiedliwości bazują na wielu narracjach.

Należy jednak pamiętać, że poglądy pracowników i innych interesariuszy są poddawane modyfikacji. Służy temu aktywna, dobrze przemyślana komunikacja wewnętrzna organizacji. Pozwala ona na stworzenie poczucia identyfikacji z organizacją i dać poczucie wspólnego źródła sprawiedliwości zróżnicowanych wynagrodzeń.

\section{Bibliografia}

Adams, J.S. (1976). Equity theory: Toward a general theory of social interaction. New York: Academic Press.

Berlo, D.K. (1960). The process of communication. New York: Holt, Rinehart \& Winston. Bies, R.J., Moag, J.F. (1986). Interactional justice: Communication criteria of fairness. Research on Negotiations in Organizations, 1, 43-55.

Borkowska, S. (2006). Strategie wynagrodzeń. Kraków: Oficyna Ekonomiczna. Castells, M. (2008). Siła tożsamości. Warszawa: Wydawnictwo Naukowe PWN. Colquitt, J.A., Scott, B.A., Judge, T.A., Shaw, J.C. (2006). Justice and personality: Using integrative theories to derive moderators of justice effects. Organizational Behavior and Human Decision Processes, 100, 110-127. 
Colquitt, J.A., Shaw, J.C. (2005). How should organizational justice be measured? W: J. Greenberg, J.A. Colquitt, Handbook of organizational justice. Mahwah, NJ: Lawrence Erlbaum Associates Publishers, 113-152.

Desai, S., Sondak, H., Diekmann, K. (2011). When fairness neither satisfies nor motivates: The role of risk aversion and uncertainty reduction in attenuating and reversing the fair process effect. Organizational Behavior and Human Decision Processes, 116, 32-45.

Deutsch, M. (2000). Cooperation, Competition and Conflict. W: M. Deutsch, P.T. Coleman (red.), The Handbook of Conflict Resolution: Theory and Practice. San Francisco: Jossey-Bass, 3-28.

Deutsch, M. (2005). Sprawiedliwość i konflikt. W: M. Deutsch, P. Coleman (red.), Rozwiq̨zywanie konfliktów. Kraków: Wydawnictwo Uniwersytetu Jagiellońskiego, 29-55.

Gerrig, R. (1993). Experiencing Narrative Worlds: On the Psychological Activities of Reading. New Haven: Yale University Press.

Goffman, E. (2008). Człowiek w teatrze życia codziennego. Warszawa: Aletheia.

Juchnowicz, M. (2016). Elastyczne zarzadzanie kapitałem ludzkim z perspektywy interesariuszy. Warszawa: PWE.

Juchnowicz, M. (2010). Zarządzanie przez zaangażowanie. Koncepcja. Kontrowersje. Aplikacje. Warszawa: PWE.

Juchnowicz, M., Sienkiewicz, Ł. (2006). Jak oceniać pracę? Warszawa: Diffin.

Kostera, M. (2008). Introduction to Organizational Olympians: Heroes and Villains of Organizational Myths. W: M. Kostera (red.), Organizational Olympians: Heroes and Heroines of Organizational Myths. Basingstoke: Palgrave Macmillan, 9-12.

Leventhal, G.S. (1980). What should be done with equity theory? New approaches to the study of fairness in social relationship. W: K.J. Gergen, M.S. Greenberg, R.H. Willis (red.), Social exchange: Advances in theory and research. New York: Plenum, 27-55.

Mark, M., Pearson, C. (2001). The Hero and the Outlaw. Building Extraordinary Brands Through the Power of Archetypes. New York: McGraw-Hill.

Moore, C. (2014). The Mediation Process. San Francisco: Jossey-Bass.

Pang, M., Chiu, M. (2000) Summary Introduction Distributive and procedural justice as predictors of employee outcomes in Hong Kong. Journal of Organizational Behavior, 21, 547-562.

Pocztowski, A. (2006). Zarzq̨dzanie zasobami ludzkimi. Warszawa: PWE.

Ritchie, D. (2011). "Justice is blind": A model for analyzing metaphor transformations and narratives in actual discourse. Metaphor and the Social World, 1, 70-89.

Schank, R. (1995). Tell Me A Story: Narrative and Intelligence. Northwestern: Northwestern University Press.

Sedlak, K. (2013). Total Rewards - przyszłość systemów wynagradzania, cz. I. Benefit, 5(17), s. 9-12. 
Semino, E. (1996). Language and world creation in poetry and other texts. London: Longman.

Total Reward Model Worldat Work, The Total Reward Association. https://www.worldatwork.org/docs/marketing/1610_BRO_TRModel_Update_J5613_FNL.pdf (2.07.2018).

Trzebiński, J. (2002). Narracyjne konstruowanie rzeczywistości. W: J. Trzebiński (red.), Narracja jako sposób rozumienia świata. Gdańsk: Gdańskie Wydawnictwo Psychologiczne, 15-42.

Werth, P. (1999). Text Worlds: Representing Conceptual Space in Discourse. London: Longman.

\section{Summary}

\section{Narration Models Concerning Justice of the Remuneration System}

The article presents the results of thinking about pay systems and fair preferences and links them with narrative models that support given preferences towards groups or granting remuneration. In the beginning, is discusses general system solutions of remuneration seen from the point of view of management and from the point of view of the employer. It then combines the types of justice (distributive, procedural, interpersonal and informative) with classical communication theories, in which the award of salaries was treated as a message. Then opinions are presented related to the fairness of remuneration among Polish employees. A hypothesis explaining the variation of results is put on this material. The hypothesis presents the mechanisms of narrative about what is right, what to whom and on what basis. These mechanisms are included in the model, in which the narratives are assigned labels of the Greek Gods. The article ends with a proposal of useful functions that the model can meet in communicating non-universal principles of justice and benefits for various organizational forms from the use of this model.

Keywords: fair remuneration, narration, remuneration system

\section{Dr hab. Jacek Wasilewski}

Doktor habilitowany nauk politycznych. Pracę doktorską pt. Retoryka dominacji obronił w 2004 r. na Wydziale Dziennikarstwa i Nauk Politycznych UW. Habilitację uzyskał w 2014 r. na podstawie pracy pt. Opowieści o Polsce. Retoryka narracji. 
Od roku 2011 kieruje specjalnością Dokumentalistyka, której celem jest rozwijanie multimedialnych dziennikarskich form narracyjnych. Członek Komisji Żywego Słowa Rady Języka Polskiego. Zajmuje się ekspertyzami dla sądów, KRRiTV, stacji medialnych i innych podmiotów publicznych. Współpracował z Krajową Szkołą Sędziów i Prokuratorów, prowadził zajęcia z retoryki w Okręgowej Izbie Radców Prawnych w Warszawie.

\section{Dr hab. Tomasz Rostkowski, prof. SGH}

Doktor habilitowany nauk ekonomicznych o specjalności zarządzanie. Pracownik Zakładu Zarządzania Kapitałem Ludzkim w Instytucie Kapitału Ludzkiego Szkoły Głównej Handlowej w Warszawie. Pracował w polskich i międzynarodowych firmach doradczych. Zrealizował kilkadziesiąt projektów badawczych i kilkadziesiąt projektów wdrożeniowych z zakresu rozwiązań systemowych ZKL (systemy wynagradzania, systemy ocen, zarządzanie kompetencjami), opracowywał także strategie ZKL przedsiębiorstw i instytucji publicznych. Specjalizuje się w strategicznym zarządzaniu kapitałem ludzkim i zarządzaniu w administracji publicznej. 